\title{
Geographic distribution and spatial differentiation in the color pattern of abdominal stripes of the Neotropical stingless bee Melipona quadrifasciata (Hymenoptera: Apidae)
}

\author{
Henrique Batalha-Filho 1; Gabriel A. R. Melo ${ }^{2}$ 4; Ana M. Waldschmidt ${ }^{3}$; \\ Lucio A. O. Campos ${ }^{1} \&$ Tânia M. Fernandes-Salomão ${ }^{1}$
}

\author{
${ }^{1}$ Departamento de Biologia Geral, Universidade Federal de Viçosa. 36570-000 Viçosa, Minas Gerais, Brasil. \\ ${ }^{2}$ Departamento de Zoologia, Laboratório de Biologia Comparada de Hymenoptera, Universidade Federal do Paraná. \\ Caixa Postal 19020, 81531-980 Curitiba, Paraná, Brasil. \\ ${ }^{3}$ Departamento de Ciências Biológicas, Universidade Estadual do Sudoeste da Bahia. 452000-000 Jequié, Bahia, Brasil. \\ ${ }^{4}$ Corresponding Author. E-mail: garmelo@ufpr.br
}

\begin{abstract}
Melipona quadrifasciata Lepeletier, 1836, regionally known as "mandaçaia", has been traditionally divided in two distinct subspecies: M. quadrifasciata anthidioides and M. quadrifasciata quadrifasciata. The main difference between the subspecies refers to the yellow metasomal stripes which are continuous in M. q. quadrifasciata and discontinuous in M. q. anthidioides. This study investigated the geographic differentiation in the metasomal stripes and characterized the restriction sites in the mtDNA of both chromatic types. Specimens from 198 localities were examined, and the variation observed in the pattern of stripes was grouped into distinct classes. The distribution pattern found in the present work agrees with the previously reported pattern: M. q. quadrifasciata inhabits the southern portion of the distribution, from Misiones, Argentina, southeastern Paraguay and Rio Grande do Sul to southern São Paulo, and M. q. anthidioides ranges from northeastern São Paulo to the northern Diamantina Plateau, Bahia, and westwards to the central portion of the Goiás state. It is documented for the first time the occurrence of two populations with continuous stripes inhabiting disjunct areas in relation to M. q. quadrifasciata - one in northern Minas Gerais and another in northeastern Bahia and Sergipe. The data of RFLP showed two restriction patterns, one present in $M$. q. quadrifasciata, and another in $M$. $q$. anthidioides and in populations with continuous metasomal stripes from northern Minas Gerais and northeastern Bahia and Sergipe. The observed patterns of geographic differentiation of M. quadrifasciata suggests the occurrence of repeated events of geographical isolation, followed by range expansion, that occurred probably during the cycles of climatic changes in the Pleistocene.
\end{abstract}

KEY WORDS. Atlantic forest; biogeography; mtDNA COI.

The stingless bee Melipona quadrifasciata Lepeletier, 1836 regionally known as "mandaçaia" in Brazil, is widespread throughout eastern Brazil, from Rio Grande do Sul to Paraíba states and extending westward to Misiones, in Argentina, and southeastern Paraguay (MOURE \& KERR 1950). Traditionally, this species has been divided into two distinct subspecies: $M$. quadrifasciata anthidioides Lepeletier and M. quadrifasciata quadrifasciata. The main difference between the subspecies refers to the yellow tergal stripes from the $2^{\text {nd }}$ to $5^{\text {th }}$ tergum in workers and males, which are continuous in M. q. quadrifasciata and discontinuous in M. q. anthidioides (Ducke 1916, Schwarz 1932).

The subspecies M. q. quadrifasciata is found in colder regions, comprising the southern portion of São Paulo, through Paraná, Santa Catarina and Rio Grande do Sul in the south (KeRR 1951). The subspecies M. q. anthidioides is found from northern and northeastern São Paulo state, eastward up to Paraíba (KERR 1951). In the state of São Paulo and southern Minas Gerais there is a hybridization zone between the two subspecies, where intermediary patterns of yellow tergal stripes are detected (Moure \& KeRR 1950, KeRR 1951).

The occurrence of populations bearing continuous abdominal stripes, similar to the color pattern exhibited by $M$. $q$. quadrifasciata, in areas outside the distribution range of this subspecies, is known for more than 30 years. Nogueira-Neto (1970) stated that he had received specimens of $M$. quadrifasciata from Carira, in Sergipe, displaying a pattern of tergal stripes similar to that of M. q. quadrifasciata. Also, colonies with continuous tergal stripes, similar to the subspecies from southern Brazil, from areas under semi-arid climate in northern Minas Gerais are known since the 1980's (G.A.R. Melo \& L.A.O. Campos, unpublished data). 
Some studies have showed a molecular differentiation between the subspecies of M. quadrifasciata. WALDSCHMidT et al. (2000) detected a RAPD-PCR marker, present in $M$. $q$. quadrifasciata and absent in M. q. anthidioides. WALDSCHMIDT et al. (2002), in a further population study using RAPD markers, observed two genetically distinct groups, one comprising M. $q$. quadrifasciata and another composed of M. q. anthidioides. In both studies, the samples from Januária, northern Minas Gerais, and bearing continuous tergal stripes, clustered with M. q. anthidioides.

In stingless bees, analyses of mitochondrial DNA (mtDNA) by RFLP have showed differences at both inter- and intra-specific levels. Francisco et al. (2001) characterized the mtDNA of five species of Plebeia using RFLP and detected differences in the restriction sites among them. FERnANDES-SALOMÃo et al. (2002) analyzed, via RFLP, the mtDNA of 16 species of Melipona, revealing differences among each species. MoretTo \& ARIAS (2005) observed distinct RFLP profiles in the mtDNA between the two subspecies of M. quadrifasciata. DE LA RúA et al. (2007) analyzed the differences in the RFLP pattern and sequences comprising the ITS2 ribosomal region in the nuclear DNA of Melipona beecheii and M. yucatanica and they also found intra-specific variation in both species.

The goal of the present work is to investigate the geographic differentiation in the metasomal coloration and characterize the restriction sites in the mtDNA of both morphotypes of M. quadrifasciata, as determined by the tergal stripe patterns, in order to achieve a better understanding of the evolution of their biogeographic pattern.

\section{MATERIAL AND METHODS}

Data regarding collecting localities and the pattern of tergal stripes in Melipona quadrifasciata were gathered from material deposited in the entomological collections of the Museu de Zoologia at Universidade de São Paulo (in January 21, 1987, by GARM), Coleção Entomológica J.S. Moure at Universidade Federal do Paraná (in February 4, 1988, by GARM and January 15, 2008, by GARM and HBF), Coleção P. Nogueira-Neto at the Instituto de Biociências, Universidade de São Paulo (in July 18, 1988, by GARM), Coleção Camargo at Faculdade de Filosofia, Ciências e Letras of Ribeirão Preto, Universidade de São Paulo (in November 15, 1991, by GARM), and Museu de Entomologia at Universidade Federal de Viçosa (examined by GARM and HBF in several occasions). Data from recently collected samples in northern Minas Gerais, Bahia and Sergipe, and deposited in the entomological collection of the apiary at Universidade Federal de Viçosa, were also included. Data on Argentinean and Paraguayan samples were taken from Holmberg (1903), BERTONI (1911) and Cockerell (1919). Considering that Melipona mandacaia Smith, 1863 is the sister species of M. quadrifasciata (G.A.R. Melo, unpublished data; see below), its geographic records were compiled from specimens deposited in the collection at Universidade Federal do Paraná and plotted in the distribution map.
The variation observed in the pattern of tergal stripes was grouped into four distinct classes (Fig. 1). Class A represents the pattern in which each yellow stripe is largely interrupted (Fig. 1), corresponding to the so-called M. q. anthidioides; class B also presents an interrupted pattern, but the distance between each half band is smaller than that in class A (Fig. 2); class C, represents the hybrid pattern between the extreme forms (Fig. 3); and class D comprises the pattern where the yellow stripes are continuous, corresponding to the pattern found in $M$. $q$. quadrifasciata (Fig. 4). A few specimens bearing a variant pattern, intermediate between classes $\mathrm{A}$ and $\mathrm{B}$, were observed; for practical purposes, they were included in class A. Also, specimens with continuous stripes but displaying a small medial interruption in tergum II were included in class D. The recognition of the hybrid pattern and intermediate forms were based on several controlled crosses between the extreme morphotypes (G. A. R. Melo \& L. A. O. Campos, unpublished data).

Representative specimens of the four classes of tergal stripe patterns were photographed using a Leica DFC 500 digital camera attached to a stereomicroscope Leica MZ 16. Images were captured using the software IM 50 (Image Manager) and combined using the software Auto-Montage Pro 5.03.0040.

Geographic coordinates for the localities cited in the collecting labels were obtained using the geo-referencing tool geoLoc provided by the Centro de Referência em Informação Ambiental - CRIA, available at http://splink.cria.org.br/geoloc. Preference was given to coordinates provided by Instituto Brasileiro de Geografia e Estatística - IBGE. Locality coordinates for recent samples, mainly in northern Minas Gerais, Bahia and Sergipe, were obtained in the field using a GPS device. A map of the geographic distribution was generated using the software Arcview Gis 3.2a.

The samples of M. quadrifasciata used in the present work were collected and stored in absolute ethanol and kept frozen at $-80^{\circ} \mathrm{C}$ up to their utilization. A worker bee from each of the following localities was analyzed: Itaiópolis (Santa Catarina) and Porto Alegre (Rio Grande do Sul), representing M. q. quadrifasciata; Caeté (Minas Gerais), Viçosa (Minas Gerais) and Jequié (Bahia), representing M. q. anthidioides; Urucuia and Januária, comprising the population with continuous stripes from northern Minas Gerais; Brejão and São Cristóvão, in Sergipe, representing the population with continuous stripes from northeastern Bahia and Sergipe.

The DNA extraction followed the procedure reported by FERNANDES-SAlOMÃo et al. (2005) and the samples were quantified in $0.8 \%$ agarose gel, in order to check the amount and the quality of DNA samples. A region encompassing the mtDNA COI gene was amplified, using the primers mtD7 (5' GGATCACCTGATATAGCATTCCC 3') and COI-IIR (5' GATCAATATCATTGATGACC 3') described by SimON et al. (1994) and HaLl \& SMITH (1991), respectively.

The PCR reactions comprised 50ng of genome DNA, $5 \mu \mathrm{l}$ of buffer (Promega), $3 \mu \mathrm{l}$ of $\mathrm{MgCl}_{2}(25 \mathrm{mM}), 1.5 \mu \mathrm{l}$ of each primer 

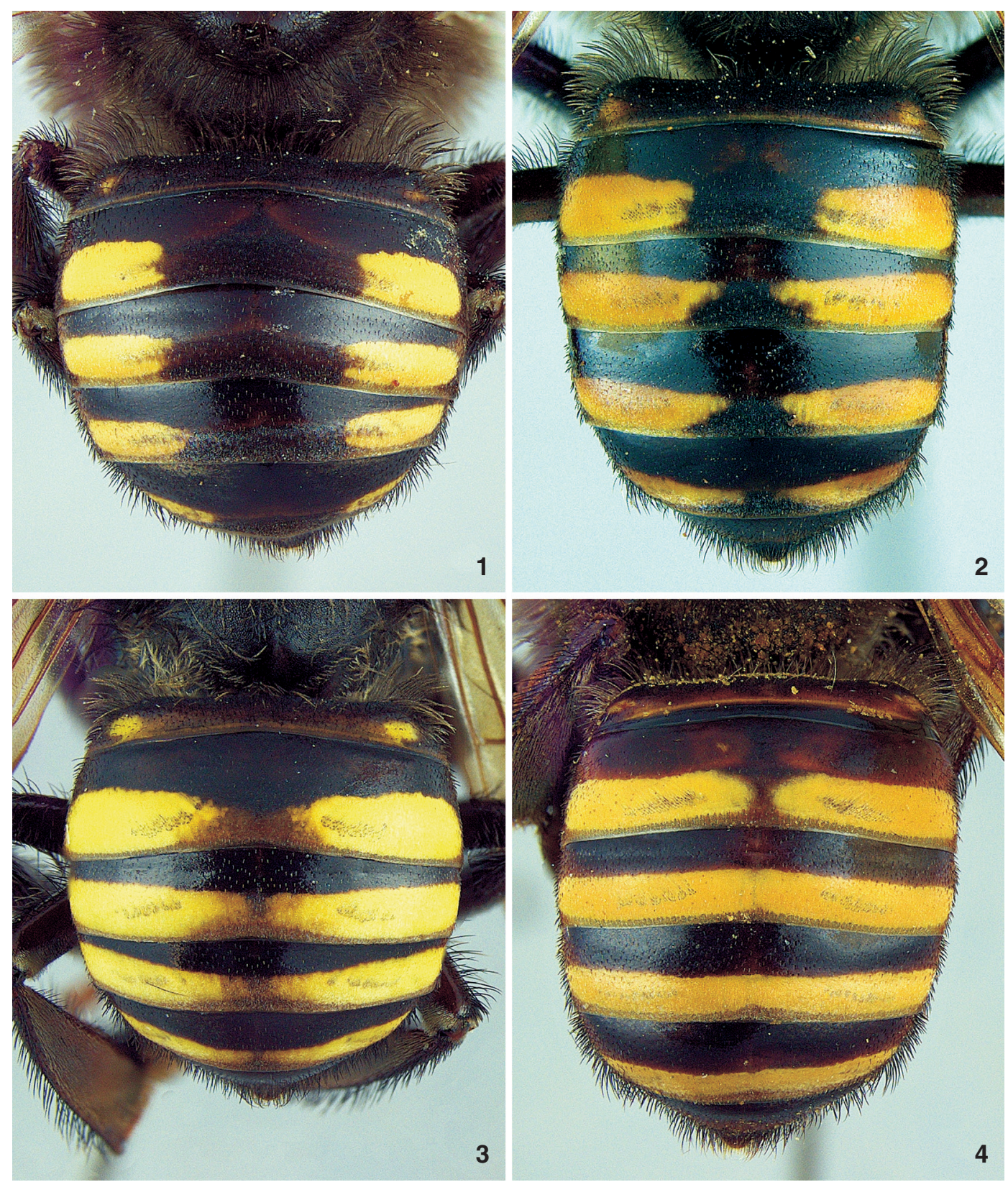

Figures 1-4. Patterns of tergal yellow stripes exhibited by workers and males of M. quadrifasciata. (1) class A, M. q. anthidioides, worker from Santa Tereza, Espírito Santo; (2) class B, worker from Três Marias, Minas Gerais; (3) class C, hybrid pattern, worker from Ourolândia, Bahia; (4) class D, M. q. quadrifasciata, worker from Campina Grande do Sul, Paraná.

$(20 \mu \mathrm{M}), 5 \mu \mathrm{l}$ of dNTPs $(2 \mathrm{mM}$ each) and $2 \mathrm{U}$ of GoTaq DNA polymerase (Promega) and water to a final volume of $50 \mu \mathrm{l}$. Each reaction was carried out in a PTC-100 thermocycler (MJ Research, Inc.), programmed to an initial denaturation step at $94^{\circ} \mathrm{C}$ for five minutes, followed by 35 cycles at $94^{\circ} \mathrm{C}$ for one minute, $45^{\circ} \mathrm{C}$ for one minute and $64^{\circ} \mathrm{C}$ for two minutes, plus a final extension step at $64^{\circ} \mathrm{C}$ for 10 minutes.

The amplified DNA fragment was digested with the enzymes DraI, EcoRI, HinfI, MboI, PstI, ScaI, XbaI and XhoI. The digestion reaction was performed at $37^{\circ} \mathrm{C}$ for lasted six hours, and the digested products were run in $2 \%$ agarose gel, stained with ethidium bromide and photodocumented under UV light. 


\section{RESULTS}

Specimens from 198 localities in Brazil were examined, comprising the entire area of occurrence of M. quadrifasciata. The distribution records are shown in figure 5 , each one represented by the symbol corresponding to the pattern of tergal stripes herein recognized. The distribution records for $M$. mandacaia are also shown in figure 5.

In general, the distribution pattern of M. quadrifasciata found in the present work agrees with the previously reported pattern for this species, i.e., M. q. quadrifasciata, a form displaying continuous tergal stripes, inhabits the southern portion of the distribution, from Rio Grande do Sul to southern São Paulo, including Misiones, in Argentina, and southeastern Paraguay to the west, whereas M. q. anthidioides, a form with interrupted stripes, ranges from northeastern São Paulo to the northern portion of Diamantina Plateau, in Bahia, and westwards to the western tip of Minas Gerais and central portion of the Goiás state.

Regarding the distribution pattern reported by previous authors, a few main differences should be pointed out: (1) Samples bearing interrupted stripes were not observed in the states of Alagoas and Sergipe, as shown in KerR (1951); (2) No specimens of $M$. quadrifasciata were recorded from Pernambuco and Paraíba, as reported by Kerr (1951) and Camargo \& Pedro (2007); (3) It is consistently documented for the first time the distribution pattern of populations with continuous stripes and inhabiting clearly disjunct areas in relation to M. q. quadrifasciata - one in northern Minas Gerais and another in northeastern Bahia and Sergipe (Fig. 5).

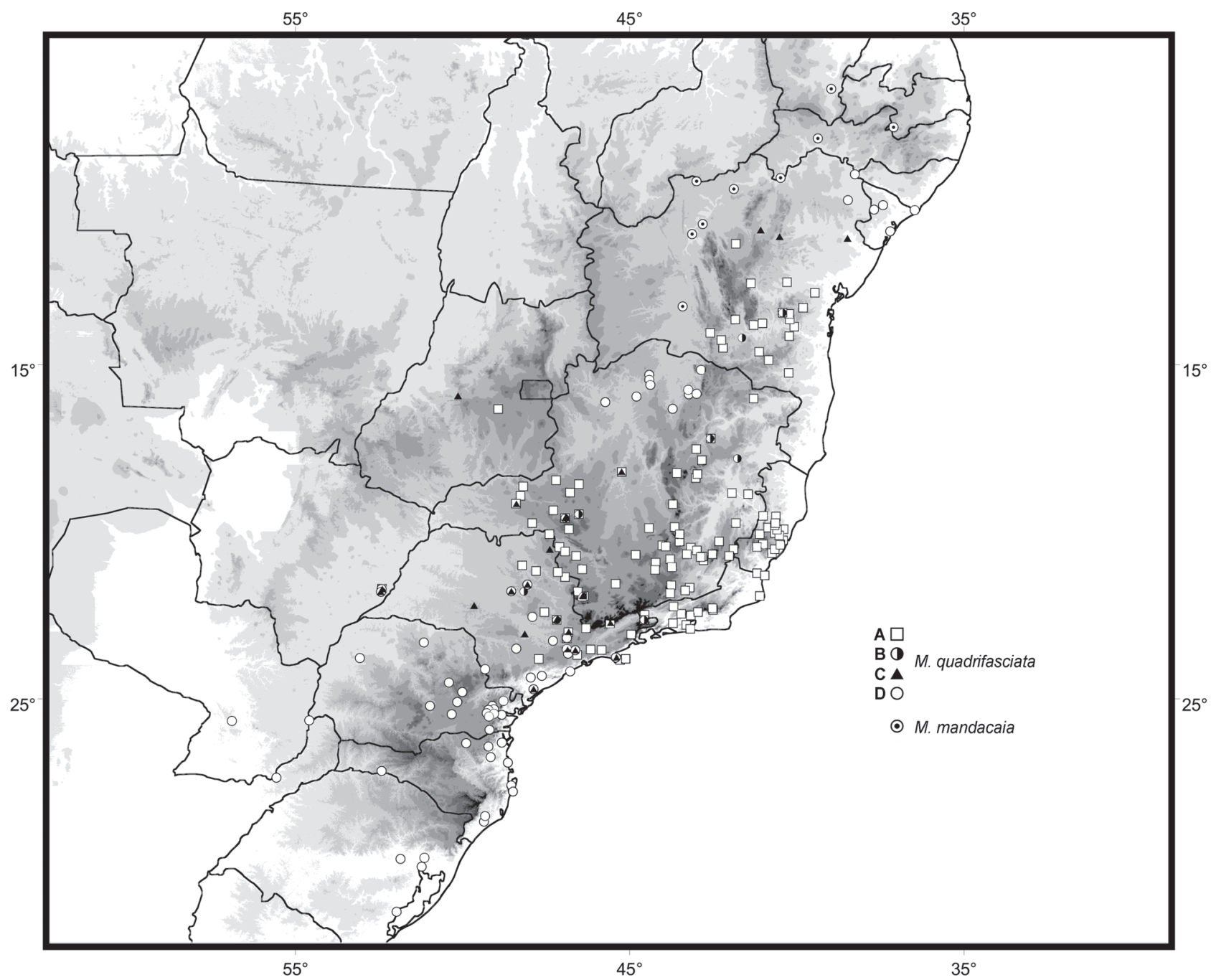

Figure 5. Distribution map for M. quadrifasciata and M. mandacaia. The records of the different patterns of tergal stripes (class A-D) in $M$. quadrifasciata are discriminated in the map (see text for characterization of the pattern classes). The different gray tones in the map are based on digital reconstruction of the relief, where the darkest tones indicate higher altitude. 
Both northern populations exhibiting a pattern of continuous stripes are associated with the basin of the São Francisco River. The former population is apparently restricted to areas of arboreal Caatinga along the middle São Francisco and some of its tributaries in Minas Gerais, such as the Verde River, on the right margin, and Urucuia River, on the left margin, while the latter population occupies Caatinga forests near the mouth of the São Francisco River. It is noteworthy that both populations inhabit areas contiguous with the southern and northern limits of the distribution of $M$. mandacaia, a species occurring along the middle to the upper São Francisco (Fig. 5).

The contact zones between populations of M. quadrifasciata bearing contrasting patterns of tergal stripes were recognized through the presence of hybrid forms (black triangles in figure 5). As previously shown by KerR (1951), the hybridization zone between M. q. quadrifasciata and M. q. anthidioides occupies the central region of the state of São Paulo, along the main channel of the river Tietê (Moure 1975), and apparently extending to the west up to eastern Mato Grosso do Sul. The hybridization zone between M. q. anthidioides and the morphotype with continuous stripes found in the northern portion of the distribution extends along a relatively narrow area in northeastern Bahia.

In relation to the population with continuous stripes in northern Minas Gerais, no specimens that could indicate hybridization with $M$. q. anthidioides were identified, although the occurrence of specimens with a hybrid phenotype in Três Marias, in central Minas Gerais, might be regarded as an evidence of contact between these populations. Individuals displaying a hybrid phenotype were also found in populations from the western tip of Minas Gerais and Goiás, in areas relatively far from the hybridization zone in São Paulo. In populations of M. q. anthidioides from northeastern Minas Gerais and southwestern Bahia, specimens exhibiting the class B phenotype were found in a few dispersed localities (Fig. 5).

Based on the distribution pattern shown in figure 5 , it seems that M. q. anthidioides is associated with higher altitude areas along the mountain ranges in Minas Gerais, Espírito Santo and Bahia, and absent from the lowlands in northern Espírito Santo and southern Bahia, as well as from lower altitude areas in the upper São Francisco river.

A fragment of about $1700 \mathrm{bp}$, encompassing the mtDNA COI gene of each specimen was amplified and digested. From the eight enzymes tested, EcoRI, PstI, ScaI, XbaI and XhoI failed in digesting the amplified DNA fragment, while the other provided restriction fragments. The restriction pattern after digestion with DraI was identical in all samples, while Hinfl and $\mathrm{MboI}$ generated polymorphic profiles.

Five restriction fragments $(970,240,180,190$, and 120 bp) were produced by the enzyme DraI, corresponding to four restriction sites, similar in all analyzed samples. The enzyme Hinfl generated two restriction patterns: (1) one restricted to samples of M. q. quadrifasciata (fragments of 950, 320, 280, and $150 \mathrm{bp}$ ), corresponding to the localities Itaiópolis and Porto Alegre; and
(2) another present in the remaining studied localities (Caeté, Viçosa, Jequié, Urucuia, Januária, Brejão and São Cristóvão) with fragments of 950, 600 and $150 \mathrm{bp}$ (Fig. 6). Polymorphic profiles, comprising fragments of $640,340,320,230$, and $170 \mathrm{bp}$, were obtained by the enzyme MboI, following the pattern seen with Hinfl: one pattern was found in samples of M. q. quadrifasciata, and the second pattern was present in the remaining localities (fragments of 600, 380, 320, 230 and $170 \mathrm{bp}$ ).

The RFLP data are only partially congruent with the geographic distribution of the tergal color patterns. The samples with continuous stripes belonging to M. q. quadrifasciata presented distinct restriction patterns in relation to those from the other analyzed samples. The samples bearing continuous stripes from northern Minas Gerais and northeastern Bahia and Sergipe, however, exhibited the same restriction pattern observed in samples of M. q. anthidioides.



Figure 6. Hinfl RFLP patterns of a fragment of the gene COI in $M$. quadrifasciata. Locality data for the samples are: 1) Viçosa, Minas Gerais; 2) Caeté, Minas Gerais; 3) Jequié, Bahia; 4) Urucuia, Minas Gerais; 5) Januária, Minas Gerais; 6) Itaiópolis, Santa Catarina; 7) Porto Alegre, Rio Grande do Sul; 8) Brejão, Sergipe; and 9) São Cristóvão, Sergipe. M is the GeneRuler of 100 pb DNA ladder plus (Fermentas). $\mathrm{C}$ is the undigested control of the fragment.

\section{DISCUSSION}

Melipona quadrifasciata has one of the largest geographic distributions among species of Melipona, inhabiting a large area along eastern Brazil. This species is mainly associated with the Atlantic Forest along its southern distribution range and with Cerrado (Brazilian savannah) and seasonal forests in the northern portion of its distribution. Its occurrence in such distinct 
biomes reveals a successful history of survival and reproduction under diverse climatic conditions and vegetation when compared to other species of Melipona. The occupation of mesic environments, covered by humid forests, seems to represent a derived feature exhibited by this species. The species of the subgenus Melipona (Melipona), group to which M. quadrifasciata belongs to, inhabit mainly dry and seasonal forests, such as for instance M. mandacaia in northeastern Brazil (G.A.R. Melo, unpublished data).

The geographic differentiation of M. quadrifasciata, bearing forms with distinct tergal stripe patterns at different regions, reflects a complex evolutionary history. The maintenance of two distinguishable patterns of metasomal coloration between M. q. quadrifasciata and M. q. anthidioides has been related to recent ecological features, such as adaptation to distinct climatic conditions (Kerr 1951, Moure 1975, Camargo \& Pedro 2007). However, the occurrence of additional populations bearing continuous tergal stripes in two separate regions suggests that vicariant historical events might have taken place. Based on the present scenario, these disjunct populations bearing continuous stripes would represent remaining descendants of a larger population that became fragmented.

This hypothesis is supported by comparisons between $M$. quadrifasciata and M. mandacaia. Within M. (Melipona), M. mandacaia is the closest species to M. quadrifasciata and, based on several morphological similarities found in workers and males and nest architecture, they can be considered sister-species (G.A.R. Melo, unpublished data). Similarly to other species of M. (Melipona) that possess tergal stripes, M. mandacaia displays continuous yellow stripes, indicating that the occurrence of such condition in $M$. quadrifasciata should be considered a plesiomorphy, thereby justifying giving those forms with continuous metasomal stripes the status of remaining populations. The presence of a single form possessing interrupted stripes, $M$. $q$. anthidioides, would be a result of a more recent differentiation within this group. The continuous geographic distribution of M. q. anthidioides within the central portion of the species range provides additional support to this hypothesis.

The separation between M. q. quadrifasciata and the other populations, as indicated by RFLP profiles using the enzymes Hinfl and MboI, is in agreement with the results of WALDSCHMIDT et al. (2000, 2002), who found a RAPD marker present in M. q. quadrifasciata and absent in M. q. anthidioides, as well as with MoretTo \& Arias (2005) who also distinguished both subspecies based on distinct RFLP patterns.

As observed by WALDSCHMidT et al. (2000, 2002), the samples with continuous stripes from northern Minas Gerais, and, in the present study, also from northeastern Bahia and Sergipe, were not genetically different from samples of M. q. anthidioides. The molecular data suggest that the differentiation process first involved a split between the southern populations, giving rise to M. q. quadrifasciata, and those found in the northern portion of the species range. The differentiation of the form with inter- rupted stripes, corresponding to the subspecies M. q. anthidioides, in relation to populations bearing continuous stripes in northern Minas Gerais and northeastern Bahia and Sergipe, would represent a more recent event.

The available evidence does not allow for a more precise estimate of when the differentiation process in M. quadrifasciata has started. The complexity in the observed patterns suggests the occurrence of independent events of geographical isolation, followed by range expansion. Other species of Melipona Illiger, 1806 from the Atlantic forest, such as M. bicolor and $M$. marginata, also present morphological differences over their ranges, in the north-south direction, and these distinct forms have been regarded as subspecies (CAmargo \& Pedro 2007). A similar differentiation has been reported in other animal groups, as in birds of the genus Xiphorhynchus (CABANne et al. 2007). Probably, these events took place relatively recently in the evolutionary history of these species of Melipona, most likely during the cycles of climatic changes in the Pleistocene, as revealed in Xiphorhynchus fuscus by CABANne et al. (2007).

The identification of populations bearing continuous yellow stripes and isolated in the northern portion of the species range could indicate that additional subspecies of $M$. quadrifasciata should be recognized in order to give them a taxonomical status congruent with the differentiation pattern observed for the species. Alternatively, considering the relatively low degree of differentiation within the species, the use of subspecies within $M$. quadrifasciata could be abandoned. Further studies using mtDNA haplotypes, however, should be conducted in order to elucidate the phylogeographic pattern of populations and define whether phylogroups are present or not within this species.

\section{ACKNOWLEDGMENTS}

The authors are grateful to Lorena A. Nunes and Rogério M.O. Alves for collecting some of the samples, to Lisiane D. Wendt (Taxonline - Rede Paranense de Coleções Biológicas, UFPR) for the assistance in the image capture and using the software Automontage, to $\mathrm{CNPq}$ for the grant to the HBF and FAPEMIG for the financial support.

\section{LITERATURE CITED}

Bertoni, A.W. 1911. Contribución á la biología de las avispas y abejas del Paraguay (Hymenoptera). Anales del Museo Nacional de Historia Natural de Buenos Aires, Serie 3, 15: 97-146.

Cabanne, G.S.; F.R. Santos \& C.Y. Miyaki. 2007. Phylogeography of Xiphorhynchus fuscus (Passeriformes, Dendrocolaptidae): vicariance and recent demographic expansion in southern Atlantic forest. Biological Journal of the Linnaean Society 91: 73-84.

Camargo, J.M.F. \& S.M.R. Pedro. 2007. Meliponini Lepeletier, 1836, p. 272-578. In: J.S. Moure; D. Urban \& G.A.R. Melo (Eds). Cata- 
logue of Bees (Hymenoptera, Apoidea) in the Neotropical Region. Curitiba, Sociedade Brasileira de Entomologia, XIV+1058p.

Cockerell, T.D.A. 1919. Bees in the collection of the United States Museum - 3. Proceedings of the United States National Museum 55: 167-221.

De La Rúa, P.; W. May-Itzá; J.Serrano \& J.J.G. Quezada-Euán. 2007. Sequence and RFLP analysis of the ITS2 ribossomal in two Neotropical social bees, Melipona beecheii and Melipona yucatanica (Apidae, Meliponini). Insectes Sociaux 54: 418423.

DuCKE, A. 1916. Enumeração dos hymenopteros colligidos pela Comissão e Revisão das especies de abelhas do Brasil. Commissão de Linhas Telegraphicas Estrategicas de Matto Grosso ao Amazonas 35: 1-211.

Fernandes-SAlomÃo, T.M.; J.I. Muro-Abad; L.A.O. Campos \& E.F. AraÚJo. 2002. Mitochondrial and nuclear DNA characterization in the Melipona species (Hymenoptera, Meliponini) by RFLP analysis. Hereditas 137: 229-233.

Fernandes-Salomão, T.M.; R.B. Rocha; L.A.O. Campos \& E.F. AraúJo. 2005. The first internal transcribed spacer (ITS1) of Melipona species (Hymenoptera, Apidae, Meliponini): characterization and phylogenetic analysis. Insectes Sociaux 52: 11-18.

Francisco, F.O.; D. Silvestre \& M.C. ArIAS. 2001. Mitochondrial DNA characterization of five species of Plebeia (Apidae: Meliponini): RFLP and restriction map. Apidologie 32: 323-332.

Hall, H.G. \& D.R. Sмith. 1991. Distinguishing African and European honeybee matrilines using amplified mitochondrial DNA. Proceedings of the National Academy of Sciences of United States of America 88: 4548-4552.

Holmberg, E.L. 1903. Delectus Hymenopterologicus Argentinus [...]. Anales del Museo Nacional de Historia Natural de Buenos Aires, Serie 3, 2: 377-468.
KerR, W.E. 1951. Estudos sobre a genética de populações de himenópteros em geral e dos apíneos sociais em particular. Anais da Escola Superior de Agricultura Luiz de Queiroz 8: 219-354.

Moreto, G. \& M.C. ArIAs. 2005. Detection of mitochondrial DNA restriction site differences between the subspecies of Melipona quadrifasciata Lepeletier (Hymenoptera: Apidae, Meliponini). Neotropical Entomology 34: 381-385.

Moure, J.S. 1975. Notas sobre as espécies de Melipona descritas por Lepetelier em 1836 (Hymenoptera, Apidae). Revista Brasileira de Biologia 3: 15-17.

Moure, J.S. \& W.E. KerR. 1950. Sugestões para a modificação da sistemática do gênero Melipona (Hymen. - Apoidea). Dusenia 1: 105-129.

Nogueira-Neto, P. 1970. A criação de abelhas indígenas sem ferrão (Meliponinae). São Paulo, Editora Tecnapis, $2^{\text {nd }}$ ed., 365p.

Simon, C.; F. Frati; A. Beckenbach; B. Crespi; H. Liu \& P. Flook. 1994. Evolution, weighting and phylogenetic utility of mitochondrial gene sequences and a compilation of conserved polymerase chain reaction primers. Annals of the Entomological Society of America 87: 651-701.

SCHWARZ, H.F. 1932. The genus Melipona IV. The type genus of the Meliponidae or stingless bees. Bulletin of the American Museum of Natural History 63: 231-460.

Waldschmidt, A.M.; E.G. Barros \& L.A.O. Campos. 2000. A molecular marker distinguishes the subspecies Melipona quadrifasciata quadrifasciata and Melipona quadrifasciata anthidioides (Hymenoptera: Apidae, Meliponinae). Genetics and Molecular Biology 23: 609-611.

Waldschmidt, A.M.; P. de Marco Jr; E.G. Barros \& L.A.O. Campos. 2002. Genetic analysis of Melipona quadrifasciata Lep. (Hymenoptera: Apidae, Meliponinae) with RAPD markers. Brazilian Journal of Biology 62: 923-928.

Submitted: 22.VIII.2008; Accepted: 15.VI.2009. Editorial responsibility: Claudio J.B. de Carvalho 